\title{
Diets and selective feeding by larvae of Atlantic mackerel Scomber scombrus on zooplankton*
}

\author{
William T. Peterson and Seth J. Ausubel
}

Marine Sciences Research Center, State University of New York at Stony Brook, Stony Brook, New York 11794, USA

\begin{abstract}
This paper describes the diets of 201 larvae of Atlantic mackerel Scomber scombrus $\mathrm{L}$. collected from Long Island Sound, New York (USA) during May-June 1982 and 1983. First-feeding larvae ( $3.5 \mathrm{~mm}$ in length) were phytophagous. The diets of larvae $4.5 \mathrm{~mm}$ were composed of the nauplii of Acartia hudsonica, Temora longicornis and Pseudocalanus sp. Larvae $>5 \mathrm{~mm}$ ate some copepodites of A. hudsonica and T. longicornis and smaller proportions of phytoplankton and copepod nauplii. Mackerel $\geqslant 6.5 \mathrm{~mm}$ were cannibalistic, eating larvae 3.5 to $4.5 \mathrm{~mm}$ in length. Weight of stomach contents averaged $1.8 \%$ of an individual's body weight. We calculated that, in order to satisfy its daily energy requirement, a mackerel larva must consume 25 to $75 \%$ of its body weight per day. Larvae fed selectively, taking a greater proportion of $T$. Iongicornis and Pseudocalanus sp. nauplii and a lesser proportion of $A$. hudsonica nauplii than expected by chance alone. Ivlev index values for $T$. longicornis nauplii were +0.66 , for Pseudocalanus sp., +0.25 , and for $A$. hudsonica, -0.55 . The Chesson index and Pearre's ' $C$ ' yielded the same result. We hypothesize that mackerel larvae select food primarily on the basis of prey visibility (both Pseudocalanus sp. and $T$. longicornis nauplii are more motile than A. hudsonica nauplii). Even though mackerel larvae consume large numbers of copepod nauplii per day and feed selectively on certain species, mackerel larvae are not sufficiently abundant in Long Island Sound to have an impact on copepod population dynamics.
\end{abstract}

\section{INTRODUCTION}

A paradigm of fisheries oceanography is that interannual fluctuations in the year-class strength of fish stocks is a function of variability in recruitment success (Cushing, 1975). Among fishes that have planktonic larvae, the greatest variability in the number of recruits each year is believed to occur during the transition between embryo and larval stages (Lasker, 1981). It is at this time that energy stores in the embryo's yolk sac become exhausted and the newly developing larva must locate high concentrations of appropriate zooplanktonic prey (and learn how to feed on them) within a time span of a few hours to a few days. If feeding conditions are unsuitable for whatever reason, the larva will perish. This bottleneck in the early life history of fishes is called the 'critical period' (Hjort, 1914, 1926; May, 1974).

\footnotetext{
- Contribution No. 390, Marine Sciences Research Center
}

Because of the dependence of larval fish survival on zooplankton abundance, a strong case can be made for focusing on the feeding ecology of larval fish in order to understand better the factors which most influence the success of a year class of fish. Clearly, environmental factors such as temperature, salinity and the details of coastal and estuarine circulation patterns have an overriding influence on when and where spawning activities take place (e.g. Parrish et al., 1981) and may affect egg survival. But, from the viewpoint of a newly hatched fish larva, food concentration is likely to be of much greater importance on a day-to-day basis (Lasker, 1975, 1981). Therefore, this paper focuses on the feeding ecology of larvae of Atlantic mackerel Scomber scombrus L. We describe their diets, feeding selectivity, and discuss their food habits in relation to the vertical distribution and abundance of their prey. Mechanisms that might control feeding selectivity are discussed and we speculate on the impact of the feeding activities of larval mackerel on zooplankton population dynamics. 


\section{METHODS}

Two stations in central Long Island Sound were sampled, one in $20 \mathrm{~m}$ of water, the other in $37 \mathrm{~m}$ (Fig. 1). Both Stations 2 and 4 were sampled in 1982, but only Station 4 was sampled in 1983. Cruises were made at weekly intervals from April through June of

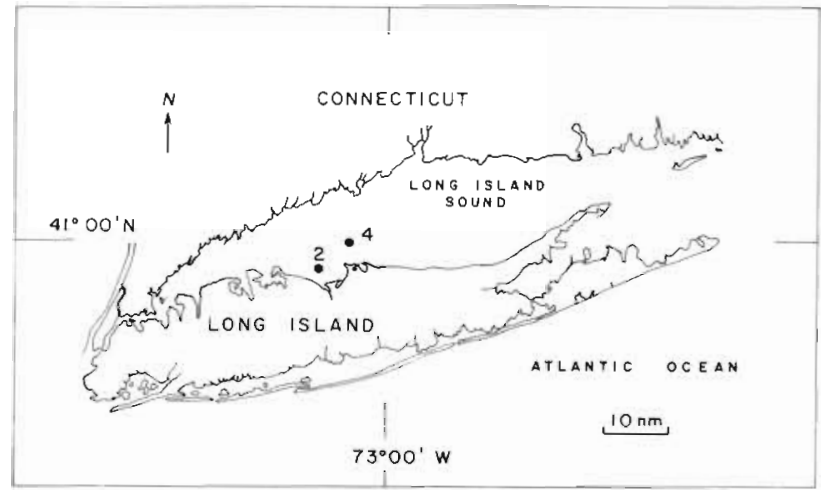

Fig. 1. Chart of Long Island Sound showing locations of stations sampled during April-June 1982 and 1983 study periods

both years. All sampling was done between 1000 and $1400 \mathrm{~h}$. During each cruise, temperature, salinity and conductivity were measured with a Beckman RS-5 induction salinometer. Water samples for chlorophyll and for zooplankton were collected from discrete depths $(1,3,5,10,15,20,30$ and $36 \mathrm{~m})$ with the aid of a Jabsco Water Puppy pump (flow rate $10 \mathrm{l} \mathrm{min}^{-1}$ ) and a $1.9 \mathrm{~cm}$ i.d. hose. From each sampling depth, a $100 \mathrm{ml}$ sample was filtered through a GF/C filter for later analysis of chlorophyll, and a 31 sample was filtered through a $64 \mu \mathrm{m}$ mesh Nitex screen, rinsed into a sample bottle and preserved with $5 \%$ buffered formalin for later enumeration of the zooplankton. In 1982 , fish eggs and larvae were sampled with a $0.75 \mathrm{~m}$ diameter, $505 \mu \mathrm{m}$ mesh net fitted with a TSK flow meter. A step-oblique tow was made by lowering the net to a depth of $10 \mathrm{~m}$, and then towing for $1 \mathrm{~min}$ at $1 \mathrm{~m}$ intervals to the surface. Towing speeds were 2 to 3 knots. A V-fin depressor was used to maintain the net at depth while towing. In 1983, a 1 m diameter, $363 \mu \mathrm{m}$ mesh net was used. Tows were made as described above with the exception that discrete depths of 1,5 , and $15 \mathrm{~m}$ were sampled.

In the laboratory, the entire zooplankton sample was counted, yielding a count of 100 to 800 items per sample. All taxa were identified to species except for Pseudocalanus because its taxonomy is uncertain (Corkett and McLaren, 1978). For the copepods, most developmental stages were enumerated separately but nauplius stages NI-NV were pooled. All fish larvae were removed from the samples and enumerated. Fish eggs were subsampled using a $5 \mathrm{ml}$ piston pipette.
For stomach-content analysis, 116 fish were randomly selected from the 1982 samples. For 1983, we selected 85 fish that appeared to be in good physical condition at the time of capture. We resorted to this non-random selection because many of the larvae collected were emaciated. Techniques for dissection of fish stomachs followed the general procedures of Last (1978a, b). Each larva was mounted on a glass microscope slide in $25 \%$ glycerin-seawater with methylene blue added. The total length of each larva was measured with the aid of an ocular micrometer prior to dissection. Stomachs were opened with sharpened insect pins, the gut contents teased free, then examined at $100 \mathrm{x}$ for identification of food items. Widths of the food items were measured whenever possible. Copepod nauplii that were too digested or damaged to be accurately identified were labelled 'unknown nauplii'. Weight of stomach contents was calculated by multiplying total number of prey taxa by their respective weights. Weights for Acartia hudsonica were taken from Durbin and Durbin (1981), those for Pseudocalanus sp. and Temora longicornis from our unpublished measurements of formalin-preserved specimens.

Daily ration and food requirements for growth of the larvae were estimated as follows. Dry weights of larvae were calculated from Hunter and Kimbrell's (1980) length-weight data for Scomber japonicus. These weights were then arbitrairly reduced by $10 \%$ because $S$. scombrus are not as thick-bodied as $S$. japonicus (Berrien, 1978). Daily growth was calculated in 2 ways, from observed changes in mean length of larvae with time (from our own length-frequency data) and from Sette's (1943) data. Daily ration was calculated assuming a gross growth efficiency of $33 \%$ (Hunter and Kimbrell, 1980).

Feeding selectivity was examined using 3 food preference indices (Ivlev, 1961; Chesson, 1978; and Pearre, 1982) and by calculating the apparent search volume (ASV). The ASV is given by:

$$
\operatorname{ASV}=\left(\frac{a_{d}}{a_{e}}\right) / F
$$

where $a_{d}=$ number of prey items of taxa ' $i$ ' in stomachs for the fish from a given sampling date and station; $a_{e}$ = abundance of the ith taxa in the zooplankton sample (in units of number per liter); $F=$ number of fish in a sample. The ASV has the units of liters fish ${ }^{-1}$. The apparent search volume represents a minimum volume searched by the average fish. The true search volume would only be equal to the ASV if the fish were $100 \%$ efficient in capturing prey. This type of feeding index has been used by Clarke (1980) and Peterson et al. (1982). 


\section{RESULTS}

\section{Distribution and abundance of mackerel eggs and larvae}

The abundances of mackerel eggs and larvae are shown in Fig. 2. Eggs first appeared in Long Island Sound on 27 April 1982 and 29 April 1983. Peak densities of $90 \mathrm{~m}^{-3}$ and $50 \mathrm{~m}^{-3}$ occurred at Station 4 on 12 May 1982 and 10 May 1983, respectively. Mackerel pooled because so few specimens were taken. In 1982 , $80 \%$ of the larvae contained food. By contrast, in 1983 less than $10 \%$ of all larvae collected contained food and $30 \%$ were emaciated and had contorted bodies. Only 31 of the 85 larvae selected for study contained food. Since so few of the larvae from 1983 had been feeding, the presentation which follows is restricted to the 1982 fish.

Most small mackerel larvae (3.5 to $4.4 \mathrm{~mm}$ ) contained only unidentifiable 'green remains' in the form
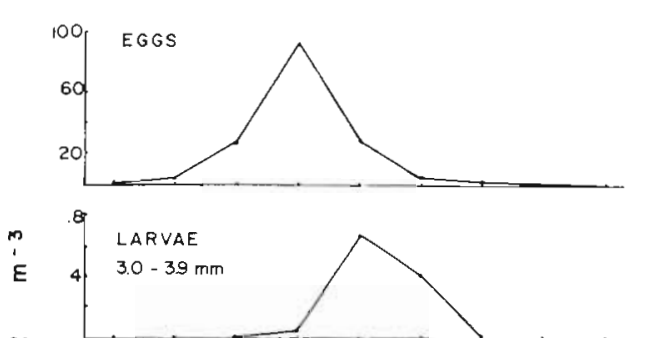

$\propto$

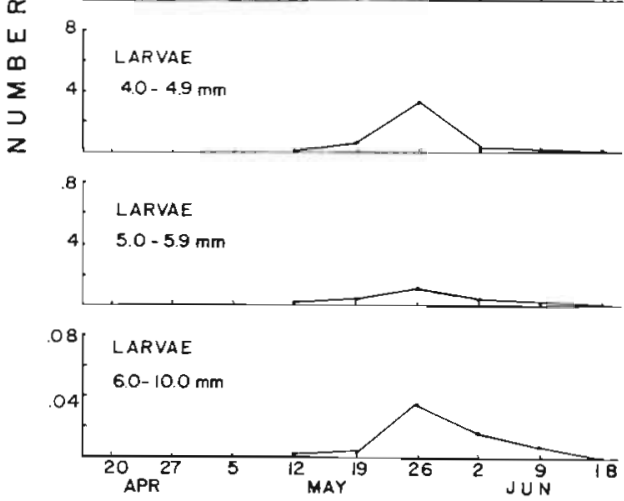

1982

larvae occurred from 12 May until 9 June 1982 and from 19 May until 1 June 1983. Peak abundances occurred at Station 4 on 26 May 1982 and 1 June 1983. From the samples collected from discrete depths in 1983, we found that eggs were most abundant above the thermocline, which occurred between depths of 5 and $15 \mathrm{~m}$ during our study. Larvae were either equally abundant at all sampling depths $(1,5$, and $15 \mathrm{~m})$ or were more abundant at a depth of $5 \mathrm{~m}$ (Ausubel, 1983).

Survival of mackerel eggs and larvae was poor in 1983 compared to 1982. Most of the eggs spawned early in the season perished and of the eggs spawned later in the season, only larvae up to $4.8 \mathrm{~mm}$ in length were taken (Fig. 2). The relatively high egg and larval mortalities in 1983 may have been due to unusually low salinities encountered in Long Island Sound in 1983. From late-April through mid-May, salinities averaged $23 \%$ compared to usual values of 25 to $27 \%$ for this period (Riley, 1956; Peterson, unpubl.).

Diets. Table 1 shows the results of stomach analysis. Fish are grouped into $0.5 \mathrm{~mm}$ length classes over the range 3.5 to $6.4 \mathrm{~mm}$. Fish greater than $6.4 \mathrm{~mm}$ were
Fig. 2. Scomber scombrus. Abundance of eggs and larvae at Station 4 averaged over the upper $10 \mathrm{~m}$ of the water column for 1982 (left) and over the upper $15 \mathrm{~m}$ for 1983 (right) of green-tinted masses of mucus. The only identifiable phytoplankton were chains of Melosira sulcata and Thalassiosira spp., 5 to 10 cells in length and several cells of Coscinodiscus lineatus. Phytoplankton were prevalent in the smaller larvae (yolk-sac) suggesting that first-feeding larvae are phytophagous. The smallest larvae also fed on copepod eggs and nauplii of both Temora longicornis and Acartia hudsonica.

The larger larvae ( $>4.4 \mathrm{~mm}$ ) had a more varied diet. The nauplii of Pseudocalanus sp., Acartia hudsonica and Temora longicornis composed most of their diet. The numbers of $A$. hudsonica and $T$. longicornis nauplii eaten were similar (a grand total of 48 and 38 , respectively), but nearly 3 times as many Pseudocalanus nauplii (117) were consumed by the 57 larvae $>4.4 \mathrm{~mm}$ examined. The mean number of nauplii per larva for those fish which contained crustacean remains increased from 2.1 for the very smallest fish to 7.5 for larvae that were 5.5 to $5.9 \mathrm{~mm}$ in length, and then decreased to 0.8 nauplii fish $^{-1}$ for the largest larvae examined (Table 1). The diets of larvae $>5.0 \mathrm{~mm}$ included some copepodites of Acartia and Temora and 
Table 1. Scomber scombrus. Stomach contents of the 116 larvae examined from samples collected in May-June 1982 (upper) and of the 85 larvae collected in May-June 1983 (lower). AC = Acartia hudsonica, TE = Temora longicornis, PS = Pseudocalanus sp, $\mathrm{UNID}=$ unidentified, $\mathrm{C}=$ copepodite, $\mathrm{SL}=$ Scomber scombrus larvae

\begin{tabular}{|c|c|c|c|c|c|c|c|c|c|c|c|c|c|c|c|c|}
\hline \multirow{3}{*}{$\begin{array}{l}\text { Larval fish } \\
\text { size class } \\
\text { (mu) }\end{array}$} & \multirow{3}{*}{$\begin{array}{l}\text { Number } \\
\text { of spe- } \\
\text { cimens }\end{array}$} & \multirow{2}{*}{\multicolumn{2}{|c|}{ Eggs }} & \multirow{2}{*}{\multicolumn{4}{|c|}{ Nauplii (NIII-NV) }} & \multicolumn{2}{|c|}{ Food items } & \multirow{2}{*}{\multicolumn{2}{|c|}{$\mathrm{Cl}$}} & \multirow{3}{*}{$\begin{array}{l}\mathrm{C} 6 \\
\mathrm{AC}\end{array}$} & \multirow[b]{3}{*}{$\mathrm{SL}$} & \multirow{3}{*}{$\begin{array}{l}\text { Percent } \\
\text { with green } \\
\text { remains }\end{array}$} & \multirow{3}{*}{$\begin{array}{l}\text { Percent with } \\
\text { crustacean } \\
\text { remains }\end{array}$} & \multirow{3}{*}{$\begin{array}{l}\text { Nauplii } \\
\text { per } \\
\text { fish }\end{array}$} \\
\hline & & & & & & & & & VI & & & & & & & \\
\hline & & $\mathrm{AC}$ & & $\mathrm{AC}$ & TE & PS & UNID & $\mathrm{AC}$ & TE & $\mathrm{AC}$ & TE & & & & & \\
\hline $3.5-3.9$ & 31 & & 2 & 5 & 8 & 6 & 7 & & 1 & & & & & 71 & 40 & 2.1 \\
\hline $4.0-4.4$ & 28 & 1 & 3 & 12 & 7 & 18 & 16 & & 3 & & & & & 75 & 61 & 3.3 \\
\hline $4.5-4.9$ & 19 & & 2 & 15 & 11 & 41 & 17 & 4 & 2 & & & & & 26 & 100 & 4.7 \\
\hline $5.0-5.4$ & 18 & & 1 & 16 & 14 & 39 & 22 & 1 & 2 & & 2 & & & 17 & 100 & 5.2 \\
\hline $5.5-5.9$ & 8 & & & 14 & 8 & 24 & 12 & 1 & 1 & 2 & 1 & & & 13 & 100 & 7.5 \\
\hline $6.0-6.4$ & 7 & & & 4 & 4 & 10 & 2 & & & & & 1 & & 20 & 100 & 2.0 \\
\hline $6.5-10.1$ & 5 & & & & $i$ & 3 & & & & & 1 & & 4 & 0 & 80 & 0.8 \\
\hline Totals & 116 & 1 & 8 & 65 & 53 & 141 & 76 & 6 & 10 & 2 & 4 & 1 & 4 & & & \\
\hline $3.2-3.4$ & 10 & & & & 3 & & & & & & & & & 10 & & \\
\hline $3.5-3.9$ & 54 & & 7 & 4 & 2 & 2 & 2 & & & & & & & 28 & 11 & 2.2 \\
\hline $4.0-4.4$ & 19 & & 7 & 1 & 1 & 2 & & & & & & & & 33 & 5 & 5.0 \\
\hline $4.5-4.9$ & 2 & & & 2 & & 2 & & & & & & & & 50 & 100 & 2.5 \\
\hline Totals & 85 & & 14 & 7 & 6 & 6 & 2 & & & & & & & & & \\
\hline
\end{tabular}

smaller proportions of nauplii and phytoplankton. Mackerel larvae $>6.0 \mathrm{~mm}$ included adult copepods in their diets. Larvae $>6.4 \mathrm{~mm}$ were cannibalistic, eating larvae of 3.5 to $4.5 \mathrm{~mm}$ in total length.

The change in diet with ontogeny is also illustrated in Fig. 3 where the relation between prey width and

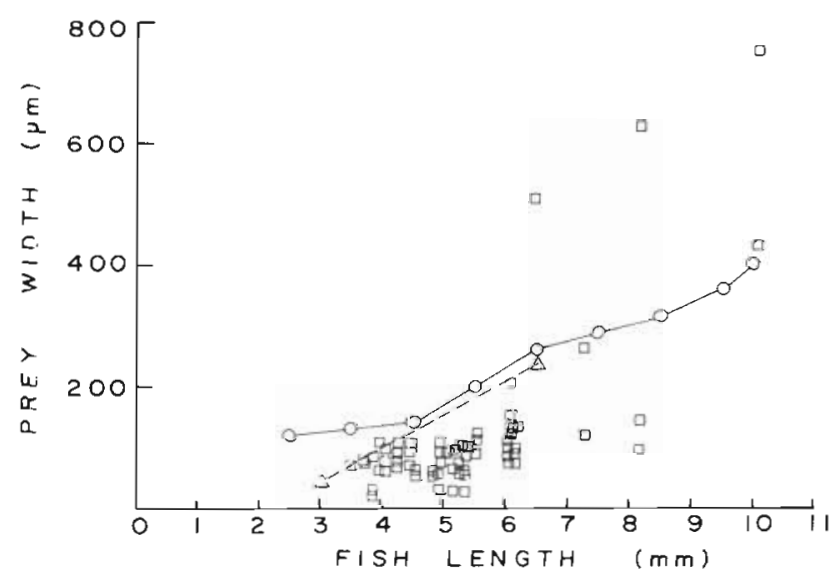

Fig. 3. Scomber scombrus. Widths of food eaten by larvae of various lengths. Our data shown by squares, Last's (1980) data for Atlantic mackerel as circles, and Hunter and Kimbrell's (1980) data for Pacific mackerel as triangles

predator length is shown. Mackerel larvae 3.5 to $6.4 \mathrm{~mm}$ fed on prey of the same widths but larvae $>6.5 \mathrm{~mm}$ took increasingly larger prey. This reflects the change in diet from a predominance of copepod nauplii (mostly Pseudocalanus and Temora NIII-NIV and Acartia NIV-NV) to nauplius stage VI, copepodites and then other mackerel larvae. Also shown on Fig. 3 are the mean prey widths for Scomber scombrus larvae from British coastal waters from Last (1980) and for S. japonicus from Hunter and Kimbrell (1980). Both $S$. scombrus and $S$. japonicus began feeding at a smaller size than our Long Island Sound specimens. Last's fish fed on small nauplii only until a length of $4.5 \mathrm{~mm}$ was achieved but his larger fish $(>8.0 \mathrm{~mm})$ fed on smaller prey items than our fish. Hunter and Kimbrell's data only include fish 3.0 to $6.5 \mathrm{~mm}$ but over this range $S$. japonicus ate larger prey than our mackerel larvae.

The feeding environment of mackerel larvae in Long Island Sound. Fig. 4 shows the vertical distribution of temperature and chlorophyll for the period 20 April through 9 June at Station 4. Vertical profiles at Station 2 were similar so they are not shown. The Sound was fairly well mixed through April as shown by the uniform distributions of the 2 variables. With the onset of seasonal stratification in early May, a thermocline developed and chlorophyll was abundant only within the upper $5 \mathrm{~m}$ of the water column. Stratification was disrupted briefly by an intense storm on 6 to 8 June which produced an isothermal water column and a homogenous distribution of chlorophyll at both stations.

Within the upper $15 \mathrm{~m}$ of the water column where larval mackerel were collected, there was a great deal of fine-scale temporal and spatial heterogeneity in the distributions of the major prey items, the nauplii of the copepods Acartia hudsonica, Temora longicorzis and Pseudocalanus sp. (Fig. 5). During the time interval when mackerel larvae were taken (12 May to 9 June 1982) the densities of all copepod nauplii combined ranged from 30 to $100 \mathrm{l}^{-1}$. In 1983 (19 May to 13 June) densities ranged from 30 to $90 \mathrm{l}^{-1}$. The most abundant species within the upper 5 to $10 \mathrm{~m}$ of the water column 

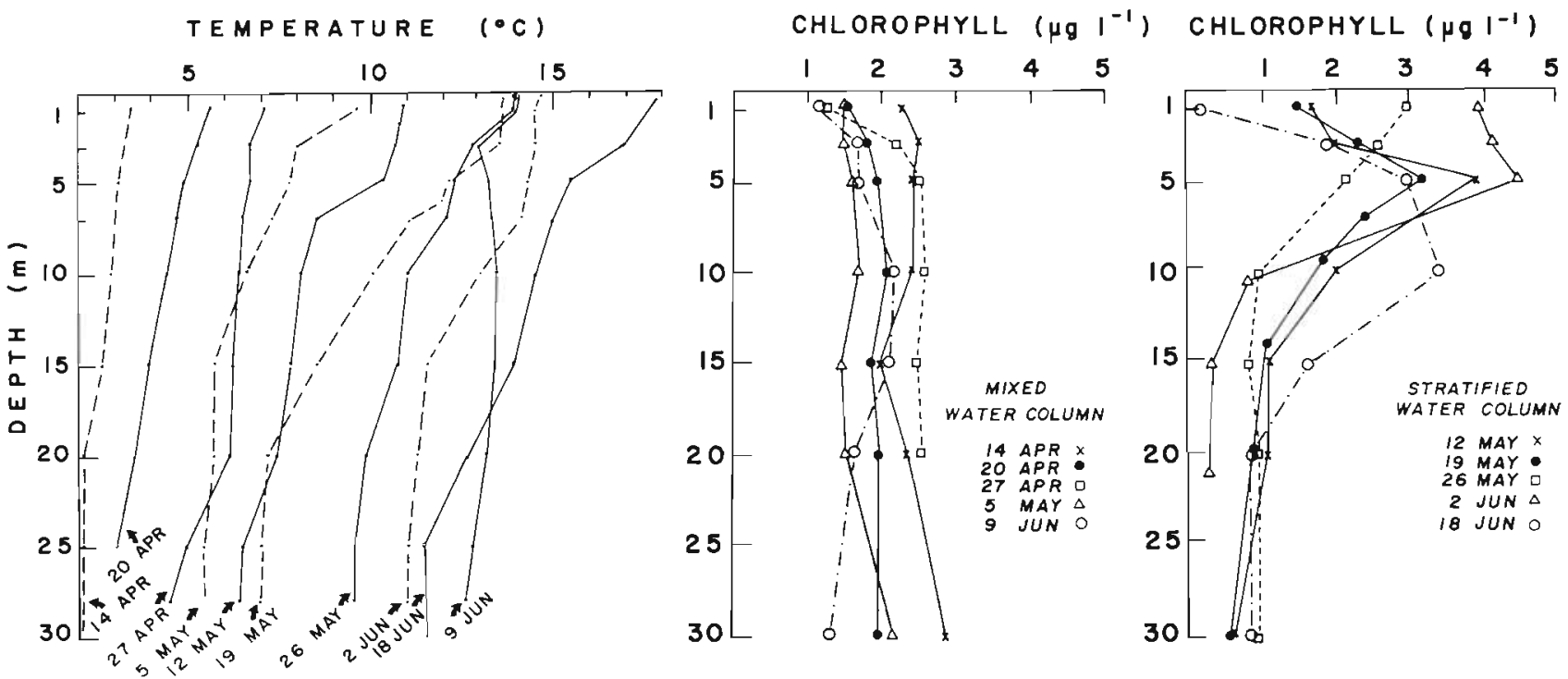

Fig. 4. Vertical distribution of temperature and chlorophyll at Station 4 during study period in 1982 . When the water column was well mixed, chlorophyll was evenly distributed with depth; but when the water column was stratified, chlorophyll was abundant only within the surface mixed layer

was $A$. hudsonica which frequently reached densities in excess of $501^{-1}, T$. longicornis were the most abundant nauplii in the zooplankton samples from MarchApril 1982 but their densities declined rapidly after 5 May at all depths (Fig. 5). In 1983, T. longicornis densities remained constant at 25 to $35 \mathrm{l}^{-1}$ in May and June. Pseudocalanus nauplii were relatively uncommon within the upper few meters of the water column during both years. They were distributed uniformly with depths during April but formed a pronounced peak at 10 to $20 \mathrm{~m}$ from May to June when maximum densities reached 20 to $301^{-1}$. Abundances of other zooplankton ranged from 0 to $251^{-1}$ (copepod eggs) and 40 to $60 \mathrm{l}^{-1}$ (copepodites). These taxa along with the copepod nauplii made up $>95 \%$ of all zooplankton retained by a $64 \mu \mathrm{m}$ mesh sieve.

Temporal changes in the vertical distribution of Acartia hudsonica, Temora longicomis and Pseudocalanus sp. nauplii in 1982 were associated with seasonal changes in the density structure of the water column. Before seasonal stratification set in, both $A$. hudsonica and Pseudocalanus were distributed moreor-less evenly throughout the upper $20 \mathrm{~m}$ of the water column and $T$. longicornis were abundant between 5 and $15 \mathrm{~m}$. After stratification in mid-May, A. hudsonica nauplii were abundant only within the surface layers $(0$ to $5 \mathrm{~m})$, Pseudocalanus between 10 and $20 \mathrm{~m}$, but $T$. longicornis numbers were reduced to nearly zero. The wind storm on 6 to 8 June had very little effect on the vertical distribution of copepod nauplii, at least based on the results of our 9 June cruise.

Feeding selectivity. Results of the food preference analysis using the various indices are shown in
Table 2. We found that mackerel larvae were selective feeders, taking a greater proportion of Pseudocalanus and Temora longicornis and a lesser proportion of Acartia hudsonica nauplii than expected by chance alone. Values for the Ivlev index for Pseudocalanus nauplii averaged +0.25 (range +0.05 to 0.43 ), for $T$. longicornis nauplii, +0.66 (range +0.50 to 0.90 ), and for $A$. hudsonica nauplii, -0.55 (range -0.50 to $-0.64)$. The results of the other indices were the same: the average values of the Chesson index were 0.24 for Pseudocalanus, 0.72 for $T$. longicornis and 0.04 for $A$. hudsonica. Pearre's ' $\mathrm{C}$ ' index indicated that in most cases these results were statistically significant at the 0.05 level. On only 3 of 15 occasions were prey items taken in the same relative proportions as they occurred in the environment: $T$. longicornis nauplii on 2 June at Stations 2 and 4, and Pseudocalanus nauplii on 19 May at Station 2.

One problem with these data is the high percentage of unidentified nauplii in stomachs of larvae $(23 \%)$. The data from 19 May at Station 4 were excluded from the calculations shown in Table 2 because the percentage of unidentified nauplii was quite high $(63 \%)$. Subsequently we recalculated the index values assuming that all of the unknown nauplii were Acartia hudsonica, the least often selected prey. This extreme assumption did not change our general conclusions. For the Ivlev index for example, the average values were -0.26 , +0.70 and +0.28 for A. hudsonica, Temora longicornis and Pseudocalanus sp., respectively, and for the Chesson Index, 0.09, 0.67 and 0.25 for the same 3 taxa.

The apparent search volumes (ASV) are also shown 

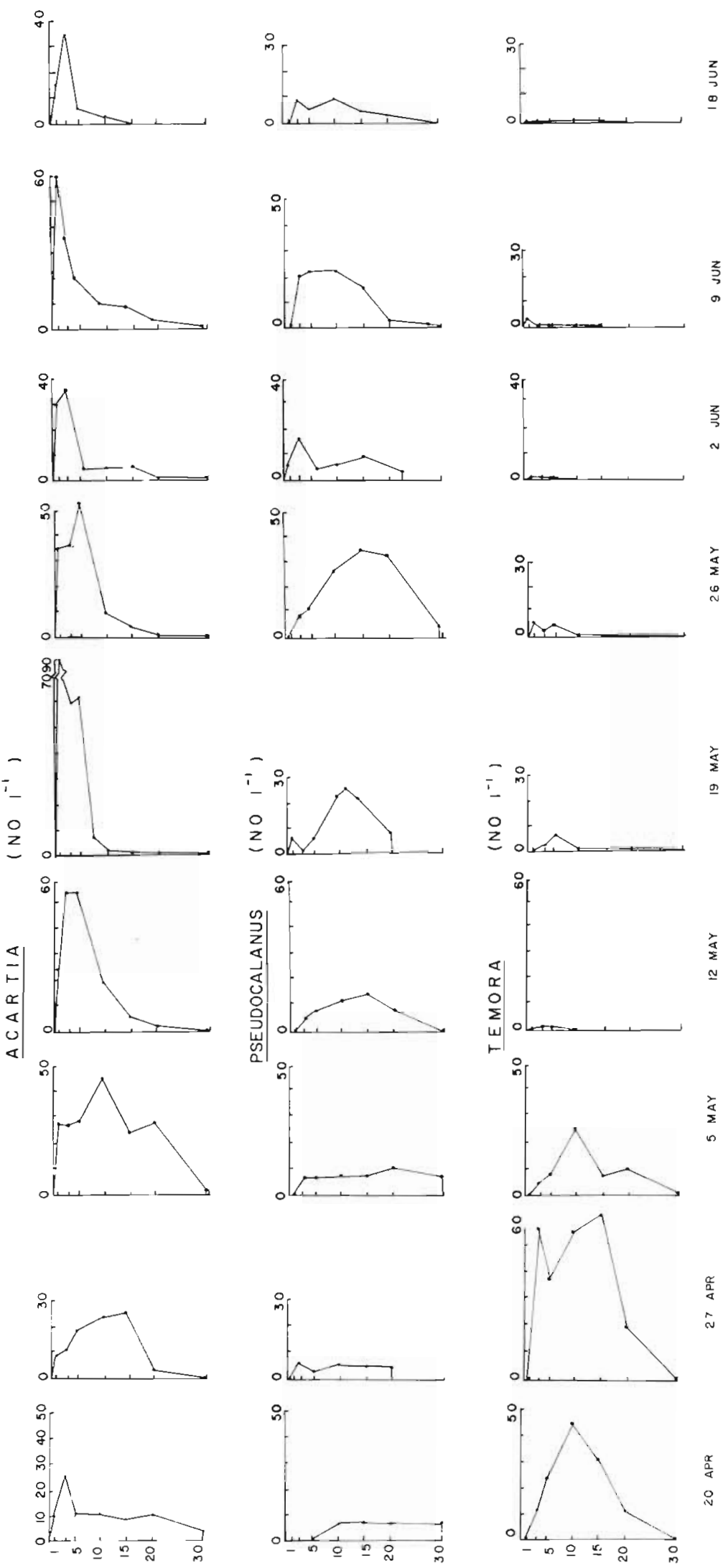

(w)

$H \perp d \exists 0$

Fig. 5. Vertical distribution of copepod nauplii at Station 4. Before the Sound became stratified, nauplii were evenly distributed over the upper $20 \mathrm{~m}$ of the water column. After stratification in early May. nauplii of Acartia hudsonica were concentrated within the upper $5 \mathrm{~m}$ of the water column, those of Pseudocalanus sp. between 10 to $20 \mathrm{~m}$, but those of Temora longicornis were reduced to nearly zero 
Table 2. Scomber scombrus. Results of food preference index calculations. See text for details. AC $=$ Acartia hudsonica, TE $=$

Temora longicornis, PS = Pseudocalanus sp.

\begin{tabular}{|c|c|c|c|c|c|c|c|c|c|c|c|c|c|c|}
\hline \multirow[t]{2}{*}{$\begin{array}{c}\text { Date } \\
(1982)\end{array}$} & \multirow[t]{2}{*}{ Station } & \multirow[t]{2}{*}{$\begin{array}{l}\text { Total } \\
\text { nauplii in } \\
\text { stomachs }\end{array}$} & \multicolumn{3}{|c|}{$\begin{array}{l}\text { Proportion } \\
\text { of nauplii } \\
\text { ingested }\end{array}$} & \multicolumn{3}{|c|}{$\begin{array}{l}\text { Proportion of } \\
\text { nauplii in } \\
\text { water column }\end{array}$} & \multicolumn{3}{|c|}{$\begin{array}{l}\text { Chesson } \\
\text { index }\end{array}$} & \multicolumn{3}{|c|}{ Ivlev index } \\
\hline & & & $\mathrm{AC}$ & $\mathrm{TE}$ & PS & $\mathrm{AC}$ & $\mathrm{TE}$ & PS & $\mathrm{AC}$ & TE & PS & $\mathrm{AC}$ & TE & PS \\
\hline 19 May & 2 & 35 & .23 & .26 & .23 & .73 & .06 & .21 & .057 & .745 & .199 & -.523 & +.610 & +.048 \\
\hline $26 \mathrm{May}$ & 2 & 51 & .18 & .18 & .43 & .82 & .01 & .17 & .011 & .868 & .122 & -.640 & +.895 & +.433 \\
\hline 26 May & 4 & 123 & .18 & .21 & .43 & .67 & .05 & .28 & .044 & .699 & .256 & -.577 & +.615 & +.211 \\
\hline 2 Jun & 2 & 70 & .23 & .06 & .50 & .73 & .02 & .25 & .059 & .564 & .376 & -.520 & +.500 & +.333 \\
\hline 2 Jun & 4 & 41 & .22 & .05 & .54 & .66 & .01 & .33 & .048 & .718 & .235 & -.500 & +.670 & +.241 \\
\hline \multirow[t]{2}{*}{$\begin{array}{l}\text { Date } \\
(1982)\end{array}$} & \multirow[t]{2}{*}{ Station } & \multicolumn{4}{|c|}{$\begin{array}{l}\text { Abundance in } \\
\text { environment }\left(\text { no } l^{-1}\right)\end{array}$} & & \multicolumn{4}{|c|}{$\begin{array}{l}\text { Apparent search } \\
\text { volume (l) }\end{array}$} & \multicolumn{4}{|c|}{ Pearre's ' $C$ ' index } \\
\hline & & $\mathrm{AC}$ & $\mathrm{TE}$ & PS & Total & & A & $\mathrm{C}$ & $\mathrm{TE}$ & PS & & $A C$ & TE & PS \\
\hline $19 \mathrm{May}$ & 2 & 56.8 & 5.0 & 17.6 & 79.4 & & .0 & 14 & .180 & .045 & & -.367 & +.327 & +.067 \\
\hline $26 \mathrm{May}$ & 2 & 50.5 & 0.6 & 10.7 & 61.8 & & .00 & 09 & .790 & .108 & & -.600 & +.309 & +.371 \\
\hline 26 May & 4 & 32.1 & 2.4 & 13.2 & 47.7 & & .0 & 16 & .260 & .096 & & -.451 & +.240 & +.224 \\
\hline 2 Jun & 2 & 27.5 & 0.6 & 9.5 & 37.6 & & $.0^{\circ}$ & 73 & .833 & .710 & & -.330 & +.055 & +.353 \\
\hline 2 Jun & 4 & 16.6 & 0.2 & 8.4 & 25.2 & & 2 & 70 & 5.0 & 1.3 & & -.420 & +.046 & +.296 \\
\hline
\end{tabular}

Table 3. Relations between dry weight of mackerel larvae, calculated dry weights of stomach contents, growth and daily ration. LIS = mackerel larvae from Long Island Sound (this study); SETTE = mackerel from the northwest Atlantic Ocean (after Sette, 1943)

\begin{tabular}{|c|c|c|c|c|c|c|c|c|c|c|c|}
\hline \multirow{3}{*}{$\begin{array}{l}\text { Length } \\
(\mathrm{mm})\end{array}$} & \multirow{3}{*}{ 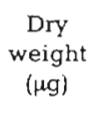 } & \multirow{3}{*}{$\begin{array}{l}\text { Weight of } \\
\text { stomach } \\
\text { contents } \\
\text { ( } \mu \mathrm{g})\end{array}$} & \multirow{3}{*}{$\begin{array}{l}\text { Percent } \\
\text { of body } \\
\text { weight }\end{array}$} & \multirow{2}{*}{\multicolumn{2}{|c|}{$\begin{array}{c}\text { Daily growth } \\
\text { of larvae } \\
(\mu g)\end{array}$}} & \multirow{2}{*}{\multicolumn{2}{|c|}{$\begin{array}{l}\text { Daily ration } \\
\qquad(\mu g)\end{array}$}} & \multirow{2}{*}{\multicolumn{2}{|c|}{$\begin{array}{l}\text { Daily ration } \\
\left.\text { (nauplii d } d^{-1}\right)\end{array}$}} & \multirow{2}{*}{\multicolumn{2}{|c|}{$\frac{\text { Ration }}{\text { Stomach contents }}$}} \\
\hline & & & & & & & & & & & \\
\hline & & & & LIS & SETTE & LIS & SETTE & LIS & SETTE & LIS & SETTE \\
\hline 3.75 & 38 & 0.79 & 2.1 & 5.9 & 9.2 & 17.7 & 27.6 & 39 & 61 & 22 & 35 \\
\hline 4.25 & 67 & 1.25 & 1.9 & 8.1 & 13.3 & 24.3 & 39.9 & 54 & 89 & 19 & 32 \\
\hline 4.75 & 107 & 1.84 & 1.7 & 10.5 & 17.6 & 31.5 & 52.8 & 70 & 117 & 19 & 29 \\
\hline 5.25 & 160 & 2.66 & 1.7 & 14.1 & 23.3 & 42.3 & 69.9 & 94 & 155 & 16 & 26 \\
\hline 5.75 & 230 & 3.81 & 1.7 & 17.6 & 29.2 & 52.8 & 87.6 & 117 & 195 & 14 & 23 \\
\hline
\end{tabular}

in Table 2. The ASV for each prey item was dissimilar because of the tendency for mackerel larvae to feed selectively. When food was abundant (19 and 26 May), search volumes for Acartia hudsonica, Temora longicornis and Pseudocalanus sp. nauplii averaged $0.13 \mathrm{l}$, 0.411 and 0.081 , respectively. On 2 June the ASV for nauplii increased 50 to 100 fold because abundances of nauplii had declined to one-fourth of the 19 and 26 May values, but also because the mackerel larvae were larger and so were eating fewer nauplii. Mean lengths of larvae had increased from $3.21 \mathrm{~mm}$ (12 May) to $3.95 \mathrm{~mm}$ (19 May), $4.72 \mathrm{~mm}$ (26 May) and $5.6 \mathrm{~mm}$ on 2 June.

Daily ration. Food requirements for growth and daily ration of our mackerel larvae are shown in Table 3. Growth and ration are shown for larvae growing at $0.11 \mathrm{~mm} \mathrm{~d}^{-1}$ (for fish from our study) and $0.18 \mathrm{~mm} \mathrm{~d}^{-1}$ (from Sette, 1943). Ration is shown in terms of both weight of crustacean food consumed and of 'Pseudocalanus NIII-NIV' equivalents. The contribution of phytoplankton to daily ration could not be calculated. The ratio, ration: weight of stomach contents, gives an estimate of the number of times per day that a mackerel larva must fill its gut in order to meet its metabolic needs.

Based on our calculations, mackerel larvae must feed at very high rates and have rapid digestion times in order to survive in Long Island Sound. An average larva must fill its gut approximately 20 to 30 times $^{-1}$ to meet its daily energy needs. This seemed unrealistically high, so we recalculated the parameters in Table 3 using only those 3 fish from each size class which contained the greatest amount of food. If mackerel larvae do in fact have rapid digestion then this 
procedure is warranted because only a small fraction of the fish captured will have just filled their stomachs. The result was that for the smallest fish $(3.75 \mathrm{~mm})$, the mean weight of stomach contents was $1.6 \mu \mathrm{g}$ and for the successively larger size classes, 2.5, 4.4, 4.9 and $8.2 \mu \mathrm{gish}^{-1}$. For fish growing at a rate of $0.11 \mathrm{~mm} \mathrm{~d}^{-1}$, these stomach weights yield a ratio of ration: stomach contents of $11,10,6.5,8.6$ and 6.4 (an average of 8.5). For fish growing at $0.18 \mathrm{~mm} \mathrm{~d}^{-1}$, the mean was 14.0 . Assuming that the fish feed only during daylight hours for a total of $15 \mathrm{~h} \mathrm{~d}^{-1}$, and that they fill their stomachs 8 to 14 times $\mathrm{d}^{-1}$, the mean digestion time is on the order of 1 to $2 \mathbf{h}$. This agrees with results reported by Houde and Schekter (1980), Kimbrell and Hunter (1980) and Bailey (1982). We conclude that Atlantic mackerel larvae must be feeding constantly.

\section{DISCUSSION}

The first evidence of spawning by Atlantic mackerel Scomber scombrus in Long Island Sound (since at least 1952) was reported by Austin (1974). He found a maximum of 200 eggs $\mathrm{m}^{-3}$ in 1973 compared to none the previous year. Maximum egg densities have averaged $75 \mathrm{~m}^{-3}$ since at least 1977 (Ausubel, 1983). The abundances of eggs and larvae in the Sound are about one order of magnitude greater than in British coastal waters (Coombs and Mitchell, 1981) and in the New York Bight (Wold, 1978). Even though egg and larval densities are extraordinarily high, Long Island Sound represents a very small portion of the total area over which Atlantic mackerel spawn so in terms of total number of recruits produced, the Sound is not an important spawning ground.

Adult mackerel arrive in Long Island Sound in April and begin to spawn on 20 April $\pm 1 \mathrm{wk}$ when water temperatures are 6 to $7^{\circ} \mathrm{C}$ (Ausubel, 1983; Ausubel and Peterson, in prep.). This precise timing of spawning is typical of both the northern and southern contingents of the northwest Atlantic mackerel stock (Ware, 1977; Berrien, 1978; Morse, 1980). Mackerel are known to spawn mostly above the thermocline (Sette, 1950; Southward and Bary, 1980; Coombs et al., 1981) so as expected, in Long Island Sound peaks in spawning activity coincide with the time of formation of the seasonal thermocline (Fig. 2 and 4), and with the onset of seasonal stratification. There is an ecological advantage associated with using the presence of a thermocline as a cue for spawning: newly hatched larvae are more assured of an adequate food supply because thermocline formation and stratification serve to concentrate both phytoplankton (Fig. 4) and copepod nauplii (Fig. 5) within the upper mixed layer. We therefore hypothesize that during a 'normal' year, a match between mackerel larvae and plankton is virtually assurred because both predator and prey abundances are controlled in large part by the same variable, i.e. thermocline formation. This would be an optimal reproductive strategy because mackerel larvae are characterized by fast growth, high metabolism and therefore have high food requirements (Hunter and Kimbrell, 1980).

Mackerel larvae in this study selected copepod nauplii by species. The most abundant prey item in the guts of larvae, Pseudocalanus nauplii, were taken in approximately the same proportions as they were encountered in the water column on some dates but were selectively ingested on other dates. The larvae ate a much larger proportion of Temora longicornis nauplii and a smaller proportion of Acartia hudsonica than expected, based on the abundance of these two taxa in the water column. Copepodites were nearly as abundant as nauplii but were seldom ingested. We hypothesize that various anatomical and behavioral differences between the nauplii of various prey species may explain why mackerel larvae feed selectively.

An anatomical difference is that although the body lengths and widths of the 3 nauplii were approximately equal, lengths including the caudal spines were strikingly different. Temora longicornis nauplii have a pair of caudal spines of unequal length which extend posteriorly to 50 and $75 \%$, respectively, of the nauplius' body length. Compared to an Acartia hudsonica or Pseudocalanus sp. nauplii, a visual predator might therefore perceive $T$. longicornis to be a much larger prey item or to notice it at a greater distance, thus increasing its apparent availability and the probability of encounter and attack

A behavioral feature that might render Temora longicornis nauplii more visible is that they are much more active than Acartia hudsonica or Pseudocalanus sp. (Peterson, pers. obs.). When feeding, an individual nauplius moves forward slowly, propelled by the mandibular palps, with the 3 pair of mouthparts arrayed like a 6-pointed star when seen in dorsal view. Feeding bouts lasted 1 to $3 \mathrm{~s}$. The nauplius may then either hang motionless in the water or dart forward a distance of 1 to $2 \mathrm{~cm}$, and then either rest or begin feeding again. Both T. longicornis and Pseudocalanus sp. nauplii have extremely vigorous escape responses. For example, we found it quite difficult to capture either of them with a pipette. A pursued nauplius seemed to 'leap' through the water and easily covered a distance of several $\mathrm{cm}$ in less than $1 \mathrm{~s}$. A. hudsonica nauplii, on the other hand, had a much more limited activity pattern. They remained motionless for much longer intervals than $T$. longicornis. They did not feed by moving slowly through the water and filtering; rather, they darted about infrequently, presumably capturing 
diatoms raptorially by chance encounter. Compared to $T$. longicornis, they were easily captured by a pipette suggesting that their escape responses are weak. The same contrast has been noted by Singarajah (1975) who reported that copepodites of $T$. Iongicornis were much more difficult to capture with a pipette and a siphon than Acartia clausi copepodites. Ware (1971), Confer and Blades (1975) and Janssen (1983) have all shown that enhanced prey motion increased the reactive distance of a visual predator. Thus, the probability of a mackerel larva spotting and attacking a fastswimming $T$. longicornis nauplius may be greater than the probability of seeing and attacking an $A$. hudsonica nauplius.

Since Temora longicornis nauplii have a more powerful escape response than Acartia hudsonica nauplii, one might expect to find that fewer $T$. longicornis were actually captured by mackerel larvae. We found the opposite result however. We hypothesize that the feeding behavior of larval mackerel may explain why $T$. longicornis were taken in greater than expected proportions. We have observed in the laboratory that mackerel larvae are persistent hunters. Individuals pursue and repeatedly attack the same prey several times until the prey has either been consumed or somehow manages to escape beyond the fish's reactive distance. Hunter (1981) reported similar feeding behavior for Pacific mackerel larvae.

We suggest that mackerel larvae preferentially hunt and consume species of prey which are the most active. Checkley (1982) found the opposite result for larvae of herring Clupea harengus fed copepodite stages of Acartia clausi and Pseudocalanus sp. In his experiments, the copepodites with the greater burst speed A. clausi were taken in lesser numbers than the slower Pseudocalanus sp. Cohen and Lough (1983) also reported that Pseudocalanus copepodites dominated the diet of $C$. harengus larvae. We conclude from these works and our own that when studying the diets and feeding dynamics of planktivorous fish, one must take into account not only prey size, prey species and prey motility patterns but also predator characteristics such as reactive distance and hunting tactics.

Even though mackerel larvae fed almost exclusively on copepod nauplii, we hypothesize that this had little effect on the dynamics of copepod populations in Long Island Sound. At peak densities observed in May, there was only about one mackerel larva per $1 \mathrm{~m}^{3}$ of water compared to 50,000 copepod nauplii and 30,000 copepodites in that same volume. When all fish larvae collected in May were pooled (primarily Atlantic mackerel, rockling and windowpane flounder) we calculated only 2 to 3 fish $\mathrm{m}^{-3}$. The exponential rate of increase in copepod nauplii numbers during the period 1 April to 20 May was approximately $0.02 \mathrm{~d}^{-1}$ (Peter- son, unpubl.). At an abundance of $50,000 \mathrm{~m}^{-3}$ and a net growth rate of $0.02 \mathrm{~d}^{-1}, 1,010$ nauplii $\mathrm{m}^{-3} \mathrm{~d}^{-1}$ would be produced. In order to remove just the nauplii produced each day a larva would have to consume 67 nauplii $\mathrm{h}^{-1}$, equivalent to approximately $450 \mu \mathrm{g}$ dry weight of nauplii $\mathrm{d}^{-1}$. This is 15 to 25 times the daily ration of a $3.75 \mathrm{~mm}$ mackerel larva. Larger larvae ( $\cong 5 \mathrm{~mm}$ ) may be capable of eating up to several hundred nauplii per day (Table 3), but their abundances are an order of magnitude less than the smaller larvae so their total impact on numbers of zooplankton would be about the same as the smaller larvae. We conclude that there are simply not enough fish larvae in Long Island Sound to have any significant impact on copepod population dynamics, a conclusion reached by Cushing (1983) for Georges Bank as well.

In this study we have attempted to describe not only the diets of mackerel larvae but also their feeding niche. This was facilitated by sampling the zooplankton at intervals of 1 wk and at many discrete depths with a plankton pump. In addition, we reduced our sampling volume to 31 in order to approximate the concentrations of prey items in the volume of water actually searched by a larval fish. Long Island Sound is so productive in April-June that such a small volume does yield an adequate sample. We did not take replicate samples so have no estimate of the importance of 'patchiness' in the horizontal plane, but it is clear from Fig. 5 that if a fish moved vertically only a few meters up or down, radically different feeding conditions would be encountered. For example, in late May, a fish feeding during the daytime at a depth of $1 \mathrm{~m}$ would find mostly Acartia hudsonica nauplii (90\%) whereas one feeding at $10 \mathrm{~m}$ would find mostly Pseudocalanus sp. nauplii ( $75 \%$ ). From the viewpoint of a fish larva, such pronounced vertical zonation of prey may be of much greater importance than variations along horizontal strata, particularly if certain species or developmental stages are preferred foods. The location of a specific prey item at any given depth would be somewhat predictable in that the fish could use environmental cues such as vertical variations in light and temperature fields to locate various depths and therefore a predictable kind of prey item. Such a hunting strategy would be useful to a fish that forms specific search images which may be the case for mackerel larvae.

In order to understand better the predator-prey interactions between larval fish and their zooplanktonic prey, much more work needs to be done on the fine-scale vertical zonation of potential prey items, particularly on the effects of seasonal changes in stratification and of mixing processes on the vertical distribution of plankton. In Long Island Sound, pronounced vertical zonation in both phytoplankton and 
zooplankton was found after the water column became stratified in May. This was accompanied by changes in the species composition of both phytoplankton and zooplankton. Intense storms can perturb the system; for example the 6 to 8 June 1982 storm produced a uniform distribution of temperature and phytoplankton over the entire $35 \mathrm{~m}$ water column, a result similar to that described by Lasker (1975). Copepod nauplii were presumably mixed throughout the water column by the storm but on our 9 June sampling date we found no evidence of any modification of the usual vertical distribution patterns of either Acartia hudsonica or Pseudocalanus sp. nauplii. Since nauplii are highly motile this may explain why their depth preferences could be re-established quickly as soon as mixing became less intense. This suggests that the effects of wind mixing on zonation of nauplii may be restricted only to period of time during a storm. If this is true, it would suggest that only first-feeding phytophagous fish larvae may be affected by wind mixing events.

Acknowledgements. This research was supported in part by the New York Sea Grant Institute. We thank Barbara Dexter, Dominick Ninivaggi, Sarah Horrigan and 4 anonymous reviewers for helpful comments on the manuscript.

\section{LITERATURE CITED}

Austin, H. (1974). Pre-operational ecological monitoring of the marine environs at the LILCO Shoreham Nuclear Power Station; Shoreham, Long Island, New York. Section V: ichthyoplankton. New York Ocean Science Laboratory, Contract SR-72-32

Ausubel, S. J. (1983). The life history and feeding ecology of larvae of Atlantic mackerel in Long Island Sound. M. S. thesis, State University of New York at Stony Brook

Bailey, K. M. (1982). The early life history of the Pacific hake, Merluccius productus. Fish. Bull. U. S. 80: 589-598

Berrien, P. L. (1978). Eggs and larvae of Scomber scombrus and Scomber japonicus in continental shelf waters between Massachusetts and Florida. Fish. Bull. U. S. 76 : 95-115

Checkley, D. M. (1982). Selective feeding by Atlantic herring (Clupea harengus) larvae on zooplankton in natural assemblages. Mar. Ecol. Prog. Ser. 9: 245-253

Chesson, J. (1978). Measuring preference in selective predation. Ecology 59: 211-215

Clarke, T. A. (1980). Diets of fourteen species of vertically migrating mesopelagic fishes in Hawaiian waters. Fish. Bull. U. S. 78: 619-639

Cohen, R. E., Lough, R. G. (1983). Prey field of larval herring (Clupea harengus) on a continental shelf spawning area. Mar. Ecol. Prog. Ser. 10: 211-222

Confer, J. L., Blades, P. I. (1975). Omnivorous zooplankton and planktivorous fish. Limnol. Oceanogr. 20: 571-579

Coombs, S. H., Mitchell, C. E. (1981). Long-term trends in the distribution and abundance and seasonal occurrence of larvae of mackerel (Scomber scombrus L.) around the British Isles, 1948-1978. J. mar. biol. Ass. U. K. 61: 343-358
Coombs, S. H., Pipe, R. K., Mitchell, C. E. (1981). The vertical distribution of eggs and larvae of blue whiting (Micromesistius poutassou) and mackerel (Scomber scombrus) in the eastern North Atlantic and North Sea. Rapp. P.-v. Reun. Cons. int. Explor. Mer 178: 188-195

Corkett, C. J., McLaren, I. A. (1978). The biology of Pseudocalanus. Adv. mar. Biol. 15: 1-231

Cushing, D. H. (1975). Marine ecology and fisheries. Cambridge University Press, London

Cushing, D. H. (1983). Are fish larvae too dilute to affect the density of their food organisms? J. Plankton Res. 5: $847-854$

Durbin, A. G., Durbin, E. G. (1981). Standing stock and estimated production rates of phytoplankton and zooplankton in Narragansett Bay, Rhode Island. Estuaries 4: $24-40$

Hjort, J. (1914). Fluctuations in the great fisheries of northern Europe. Rapp. P.-v. Reun. Cons. int. Explor. Mer 20: 1-13

Hjort, J. (1926). Fluctuations in the year classes of important food fishes. J. Cons. int. Expior. Mer 1: 5-38

Houde, E. D., Schekter, R. C. (1980). Feeding by marine fish larvae: developmental and functional responses. Environ. Biol, Fish. 5: 315-334

Hunter, J. R. (1981). Feeding ecology/predation. In: Lasker, R. (ed.) Marine fish larvae: morphology, ecology and relation to fisheries. University of Washington Sea Grant Program, Seattle, p. 34-77

Hunter, J. R., Kimbrell, C. A. (1980). Early life history of Pacific mackerel, Scomber japonicus. Fish. Bull. U. S. 78: 89-101

Ivlev, I. S. (1961). Experimental ecology of the feeding of fishes. Yale University Press, New Haven

Jansen, J. (1983). Comparison of searching behavior for zooplankton in an obligate planktivore, blueback herring (Alosa aestivalis) and a facultative planktivore, bluegill (Lepomis machrochirus). Can. J. Fish. aquat. Sci. 39: $1649-1654$

Lasker, R. (1975). Field criteria for survival of anchovy larvae: the relation between inshore chlorophyll maximum layers and successful first feeding. Fish. Bull. U. S. 73: 453-462

Lasker, R. (1981). Marine fish larvae; morphology, ecology and relation to fisheries. University of Washington Press, Seattle

Last, J. M. (1978a). The food of four species of pleuronectiform larvae in the eastem English Channel and southern North Sea. Mar. Biol. 45: 359-368

Last, J. M. (1978b). The food of three species of gadoid larvae in the eastern English Channel and southern North Sea. Mar. Biol. 48: 377-386

Last, J. M. (1980). The food of twenty species of fish larvae in the west-central North Sea. Fisheries Research Technical Report No. 60, Lowestoft

May, R. C. (1974). Larval mortality in marine fishes and the critical period concept. In: Blaxter, J. H. S. (ed.). The early life history of fishes. Springer-Verlag, Berlin, p. 3-19

Morse, W. W (1980). Spawning and fecundity of Atlantic mackereI, Scomber scombrus, in the mid-Atlantic Bight. Fish. Bull. U. S. 78: 103-108

Parrish, R. H., Nelson, C. S., Bakun, A. (1981). Transport mechanisms and reproductive success of fishes in the California Current. Biol. Oceanogr. 1: 175-203

Pearre, S. (1982). Estirnating prey preference by predators: uses of various indices, and a proposal of another based on $\mathrm{X}^{2}$. Can. J. Fish. aquat. Sci. 39: 914-923

Peterson, W. T., Brodeur, R. G., Pearcy, W. G. (1982). Food habits of juvenile salmon in the Oregon coastal zone, June 1979. Fish. Bull. U. S. 80: 841-851 
Riley, G. A. (1956). The oceanography of Long Island Sound, 1952-1954. II: Physical oceanography. Bull. Bingham Oceanogr. Coll. 15: 15-46

Sette, O. (1943). Biology of the Atlantic mackerel (Scomber scombrus) of North America. Part I: Early life history, including growth, drift, and mortality of the egg and larval populations. U. S. Fish. Wildl. Serv. Fish. Bull. 38: 149-237

Sette, O. (1950). Biology of the Atlantic mackerel (Scomber scombrus) of North America. Part II: Migrations and habits. U. S. Fish. Wildl. Serv. Fish. Bull. 51: 249-358

Singarajah, K. V. (1975). Escape reactions of zooplankton: effects of light and turbulence. J. mar. biol. Ass. U. K. 55: $627-639$

Southward, A. J., Bary, B. McK. (1980). Observations on the vertical distribution of eggs and larvae of mackerel and other teleosts in the Celtic Sea and on the sampling performance of different nets in relation to stock evaluation. J. mar. biol. Ass. U. K. 60: 295-311

Ware, D. M. (1971). The predatory behavior of rainbow trout. Dissertation, University of British Columbia, Vancouver, B. C., Canada

Ware, D. M. (1977). Spawning time and egg size of Atlantic mackerel, Scomber scombrus, in relation to the plankton. J. Fish. Res. Bd Can. 34: 2308-2315

Wold, E. (1978). Atlantic coastal experiment, Survey cruises, July 1974-Sept. 1975. Data Report. Vol. 2: zooplankton and ichthyoplankton. Brookhaven National Laboratory, Report BNL-24771

This paper was presented by Dr. K. Sherman; it was accepted for printing on January 29, 1984 